\title{
SIMULASI KEAMANAN JARINGAN DENGAN METODE DHCP SNOOPING DAN VLAN
}

\author{
ZAENI MIFTAH \\ Program Studi Teknik Informatika \\ Sekolah Tinggi Manajemen Informatika dan Komputer Eresha \\ Email : zaenimiftah02@gmail.com
}

\begin{abstract}
Abstrak. Jaringan komputer dan internet merupakan kebutuhan bagi masyarakat. Banyaknya pengguna jaringan komputer dan internet menyebabkan keamanan pada jaringan komputer dan internet merupakan hal yang sangat dibutuhkan pada saat ini, khususnya di lingkungan STMIK Eresha. Banyak upaya yang dilakukan untuk memberikan pelayanan jaringan komputer dan internet seperti peningkatan bandwith, memberikan keamanan pada jaringan komputer dan internet seperti menggunakan ACL, Switchport Security, Vlan dan DHCP Snooping. DHCP Snooping merupakan keamanan pada jaringan komputer dan internet yang digunakan untuk mencegah atau memfilter adanya server lain yang tidak dipercaya dalam memberikan akses jaringan kepada pengguna atau komputer client. Peneliti akan melakukan analisis perbandingan terhadap jaringan komputer dan internet dengan metode DHCP Snooping dan tanpa DHCP Snooping menggunakan software simulasi Cisco Packet Tracer. Hasil perbandingan keamanan jaringan komputer dan internet tanpa DHCP Snooping yaitu beberapa komputer client tidak aman serta tidak dapat terhubung ke server sedangkan apabila menggunakan metode $D H C P$ Snooping mampu melakukan filter atau penyaringan terhadap server yang tidak dipercaya sehingga jaringan komputer dan internet menjadi aman.
\end{abstract}

Kata Kunci: keamanan jaringan, VLAN, DHCP snooping

Abstract. Computer and internet networks are a necessity for society. The large number of users of computer network and internet cause security in computer and internet network is very needed at this time, especially in STMIK Eresha environment. Many efforts are made to provide computer network services and the Internet such as increased bandwidth, providing security on computer networks and the Internet such as using ACL, Switchport Security, Vlan and DHCP Snooping. DHCP Snooping is a security on computer and internet networks that are used to prevent or filter the existence of other servers that are not trusted in providing network access to the user or client computer. The author will perform comparative analysis of computer network and internet with Snooping DHCP method and without DHCP Snooping using Cisco Packet Tracer simulation software. The result of comparison of computer network security and internet without DHCP Snooping that is some client computer is not secure and cannot connect to server while if using DHCP method Snooping able to filter or filtering against server that is not trusted so that computer network and internet become secure.

Keyword: network security, VLAN, DHCP snooping

\section{PENDAHULUAN}

Jaringan internet merupakan kebutuhan bagi masyarakat umum dalam rangka mencari informasi berita, sarana transportasi, lokasi, transaksi bisnis online sampai pada transaksi perbankan secara online. Bagi pelajar jaringan internet sering digunakan untuk pembelajaran online, akses sistem akademik, akses perpustakaan online dan lain-lain. Semakin banyaknya 
pengguna yang memanfaatkan jaringan internet maka keamanan jaringan komputer merupakan hal yang sangat dibutuhkan khususnya di lingkungan STMIK Eresha. Keamanan jaringan komputer melibatkan banyak aspek, mulai dari perlindungan peralatan secara fisik seperti perangkat keras, akses terhadap sumberdaya jaringan, perlindungan data serta informasi yang berada pada jaringan untuk mencegah terjadinya pencurian data.

Keamanan jaringan komputer di lingkungan STMIK Eresha masih memiliki kekurangan karena akses jaringan hanya diberikan melalui $D H C P$ Server. Hal ini menyebabkan terjadinya serangan berupa DHCP Rogue yaitu DHCP Server palsu yang memberikan alamat gateway yang salah pada komputer client sehingga komputer tidak dapat terhubung pada sebuah jaringan dan internet. Keamanan jaringan yang belum baik menyebabkan akses internet pada jaringan sering terjadi masalah dikarenakan serangan terhadap DHCP Server yang dilakukan oleh orang yang tidak bertanggung jawab. Oleh karena itu maka metode keamanan pada jaringan komputer perlu ditingkatkan, misalnya dengan menggunakan DHCP snooping. Metode DHCP snooping diharapkan dapat membantu mengatasi masalah keamanan jaringan komputer dan internet.

\section{Tinjauan Pustaka} dari:

Dalam jaringan komputer diperlukan beberapa komponen perangkat jaringan yang terdiri

\section{Router}

Router merupakan perangkat jaringan yang bertanggung jawab untuk meneruskan atau mengirimkan data dari satu network ke network yang berbeda. Router sering digunakan untuk menghubungkan network yang menggunakan topologi Bus, Ring dan Star (Sofana, 2009).

Router cisco mempunyai komponen-komponen diantaranya:

a. RAM (Random Acces Memory)

RAM termasuk Memori Volatile yaitu menyimpan konfigurasi sementara selama router menyala seperti Running IOS, Running Konfigurasi File, IP Routing dan Table $A R P$

b. ROM (Random Only Memory)

ROM termasuk Non-volatile yaitu menyimpan secara permanen seperti Instruksi Bootup, Software Diagnostik Dasar.

c. NVRAM (Non-volatile RAM)

NVRAM termasuk Non-volatile yaitu menyimpan secara permanen seperti startup configuration file.

d. Flash Memory

Flash termasuk Non-volatile yaitu menyimpan secara permanen seperti IOS image sistem operasi (cisco IOS).

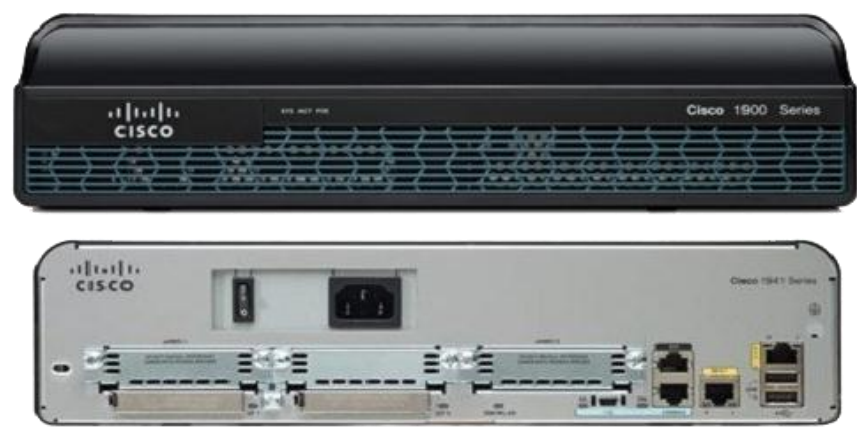

Gambar 1. Perangkat Cisco Router 


\section{Switch}

Switch merupakan perangkat yang berfungsi untuk menghubungkan beberapa komputer ataupun perangkat jaringan agar dapat berbagi sumber daya. Switch juga merupakan perangkat keras yang memungkinkan terjadinya distribusi paket data antar komputer dalam jaringan dan mampu untuk mengenali topologi jaringan dibanyak layer sehingga data dapat langsung sampai ketujuan (Sulaiman, 2016).

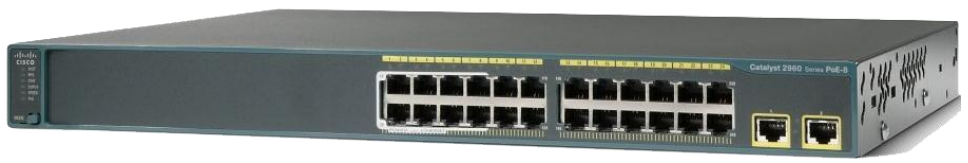

Gambar 2. Perangkat Switch Cisco

3. Wireless Access Point

Wireless Access Point merupakan suatu perangkat yang digunakan untuk menghubungkan pengguna dengan jaringan komputer biasa. Access Point menerima data dari pengguna dalam bentuk gelombang berfrekuensi radio kemudian meneruskannya ke jaringan kabel. Access Point juga mengirimkan data dari jaringan ke pengguna dalam bentuk gelombang radio. (Prasetiono, 2010).

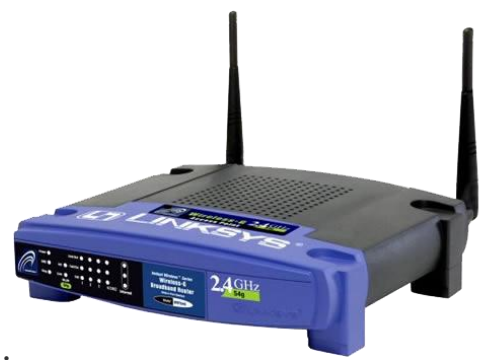

Gambar 3. Perangkat Access Point

\section{VLAN}

VLAN adalah suatu jaringan yang dibangun berdasarkan kelompok atau grup dalam satu network dimana beberapa komputer hanya dapat berkomunikasi sesuai dengan kelompok atau grup yang dibuat. VLAN dapat meningkatkan performance pada jaringan. VLAN adalah tipe baru arsitektur LAN yang menggunakan switch cerdas berkecepatan tinggi. Tidak seperti jenis LAN biasa yang secara fisik menghubungkan komputer ke segmen LAN, VLAN menetapkan komputer ke segmen LAN oleh perangkat lunak. VLAN telah distandarkan sebagai IEEE802.1q dan IEEE802.1p (Tarkaa, Iannah, \& Iber, 2017).

Beberapa keuntungan penggunaan VLAN antara lain:

a. Keamanan pada jaringan. Keamanan pada sebuah jaringan dapat dilakukan dalam bentuk pemisahan terhadap segmentasi jaringan secara logika.

b. Penghematan anggaran. Penghematan dari penggunaan bandwidth yang ada dan dari upgrade perluasan network yang bisa jadi mahal.

c. Meningkatnya kemampuan jaringan. Pembagian jaringan layer 2 ke dalam beberapa kelompok broadcast domain yang lebih kecil, yang tentunya akan mengurangi lalu lintas paket yang tidak dibutuhkan dalam jaringan.

d. Memperkecil Broadcast Domain. Pembagian jaringan ke dalam VLAN akan mengurangi banyaknya device yang berpartisipasi dalam pembuatan broadcast storm. Hal ini terjadinya karena adanya pembatasan broadcast domain. 
e. Lebih effisien dalam pengembangan dan pengelolaan teknologi jaringan. VLAN memudahkan manajemen jaringan karena pengguna yang membutuhkan sumber daya yang dibutuhkan terbagi dalam segmen yang sama.

5. DHCP Server

DHCP Server adalah perangkat jaringan yang memiliki kemampuan dalam memberikan atau meminjamkan alamat IP pada Komputer client yang terhubung dalam sebuah jaringan sehingga Komputer dapat berkomunikasi. DHCP dapat membantu menghemat penggunaan alamat IP karena alamat IP tidak perlu lagi diberikan secara permanen pada masing-masing komputer client.

DHCP Server berkerja di mana komputer client yang terhubung dalam sebuah jaringan melakukan permintaan IP Address pada komputer server DHCP yang memiliki persediaan alamat IP Komputer di dalam database-nya. Proses tersebut dikenal DHCP DISCOVER. Selanjutnya, server DHCP melakukan pengecekan pada database apakah masih tersedia alamat IP atau tidak. Jika alamat IP masih tersedia pada database maka komputer server DHCP memberikan informasi serta menawarkan pada komputer client yang minta alamat IP dan proses ini dikenal dengan DHCP OFFER. Proses selanjutnya komputer client menerima penawaran tersebut dari komputer server DHCP dengan meminta alamat yang ditawarkan tersebut untuk digunakan sebagai alamat IP komputernya proses ini dikenal dengan DHCP REQUEST. Proses terakhir adalah komputer server DHCP memindahkan alamat IP dari database komputer server DHCP ke komputer client sehingga komputer client diakui telah menggunakan alamat IP yang diberikan oleh komputer server DHCP, proses ini disebut DHCPACK.

6. Serangan pada Jaringan Komputer (BPPT, 2014)

a. Sniffer adalah sebuah upaya yang dilakukan untuk menangkap atau mencuri data yang dikirim melalui jaringan komputer. Fungsi sniffer bagi pengelola bisa untuk memantau data yang sedang dikirim pada jaringan. Packet Sniffing adalah sebuah metode serangan dengan cara mendengarkan seluruh paket yang lewat pada sebuah media komunikasi, baik media kabel maupun radio. Setelah paket-paket yang lewat itu didapatkan, paket-paket tersebut kemudian disusun ulang sehingga data yang dikirimkan oleh sebuah pihak dapat dicuri oleh pihak yang tidak berwenang.

b. Spoofing (penyamaran) adalah upaya menyembunyikan atau memalsukan alamat komputer sehingga sistem akan kesulitan menentukan darimana komputer mentransmisikan data. Spoofing adalah teknik melakukan penyamaran sehingga terdeteksi sebagai identitas yang bukan sebenarnya

7. DHCP Snooping

Komputer yang terhubung dalam jaringan akan mendapatkan alamat ip yang diberikan dari server DHCP sehingga komputer dapat berkomunikasi. DHCP snooping adalah fitur keamanan yang berfungsi seperti firewall di mana komputer yang terhubung dengan server DHCP akan mendapatkan alamat IP dari sumber yang terpercaya sedangkan sumber atau server DHCP yang tidak tepercaya tidak mendapat ijin untuk memberikan alamat IP yang dimiliki. DHCP snooping merupakan solusi yang tepat untuk mengatasi masalah keamanan jaringan yang lebih baik (Ariyadi, 2017).

8. Cisco Packet Tracer

Cisco Packet Tracer adalah salah satu aplikasi yang dibuat oleh perusahaan Cisco yang berlokasi di San Francisco, California. Cisco didirikan pada tahun 1984. Cisco Packet Tracer sebagai alat simulasi yang digunakan dalam pembelajaran jaringan komputer khususnya produk Cisco. Dengan menggunakan aplikasi cisco packet tracer, simulasi data mengenai jaringan dapat dimanfaatkan menjadi informasi tentang keadaan koneksi suatu 
komputer dalam suatu jaringan, apabila terjadi masalah dalam interkoneksi jaringan (Mufadhol, 2012).

\section{METODE}

Metode penelitian yang digunakan terhadap penelitian tentang keamanan jaringan komputer dan internet dengan menggunakan software simulasi Cisco Packet Tracer 7.1. Adapun topologi yang digunakan dalam penelitian ini, peneliti akan menggunakan dua router cisco di mana router pertama sebagai Server DHCP trusted/yang dipercaya sedangkan yang lainnya sebagai pembanding yaitu Server DHCP Untrusted/tidak dipercaya, 1 unit Access Point, 2 unit Server, 4 unit PC, 9 unit Laptop dan 3 unit Switch.

Adapun langkah-langkah pengujian keamanan jaringan komputer menggunakan $D H C P$ Snooping adalah sebagai berikut:

1. Mendesain topologi jaringan menggunakan Software Simulasi Cisco Packet Tracer.

2. Konfigurasi pada setiap device seperti pada Router, Switch, dan Server.

3. Analisis perbandingan penggunaan fungsi DHCP Snooping dan tanpa DHCP Snooping.

4. Pengujian konektifitas pada jaringan

Flowchart penelitian ditunjukkan oleh gambar berikut:

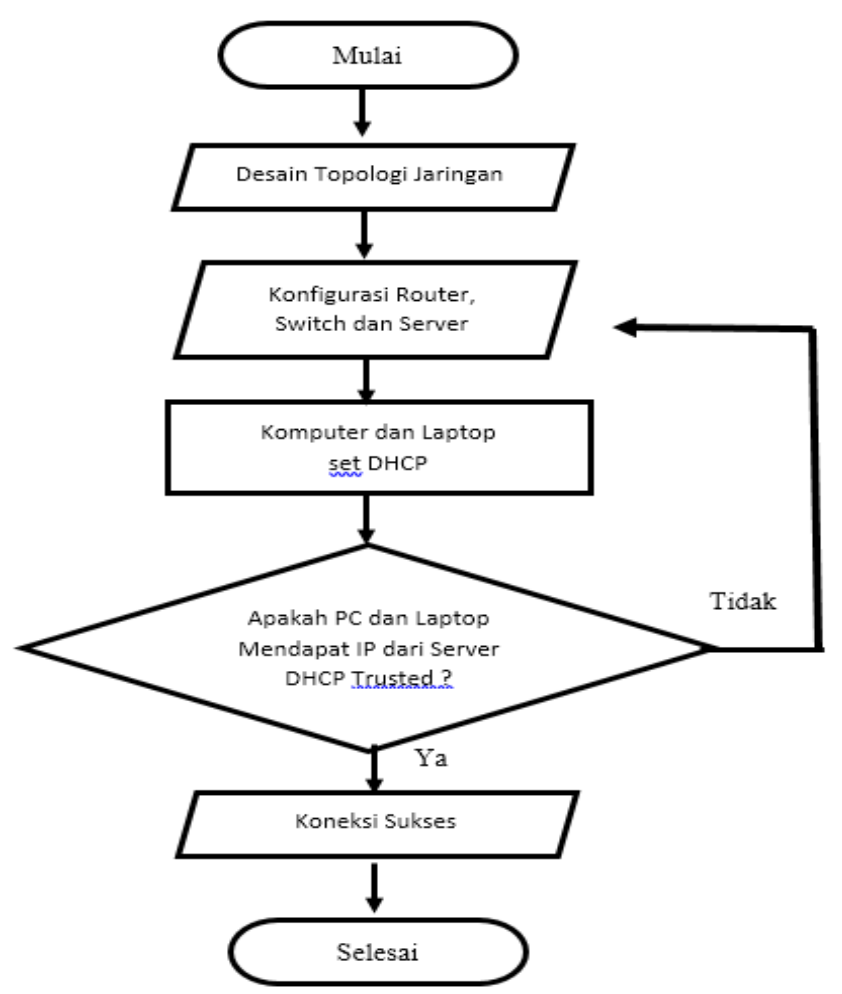

Gambar 4. Flowchart Penelitian

\section{HASIL DAN PEMBAHASAN}

Hasil dari perancangan jaringan komputer dapat dilihat pada Gambar 5 berikut, di mana Switch akan dikonfigurasi tanpa menggunakan DHCP Snooping dan VLAN. 


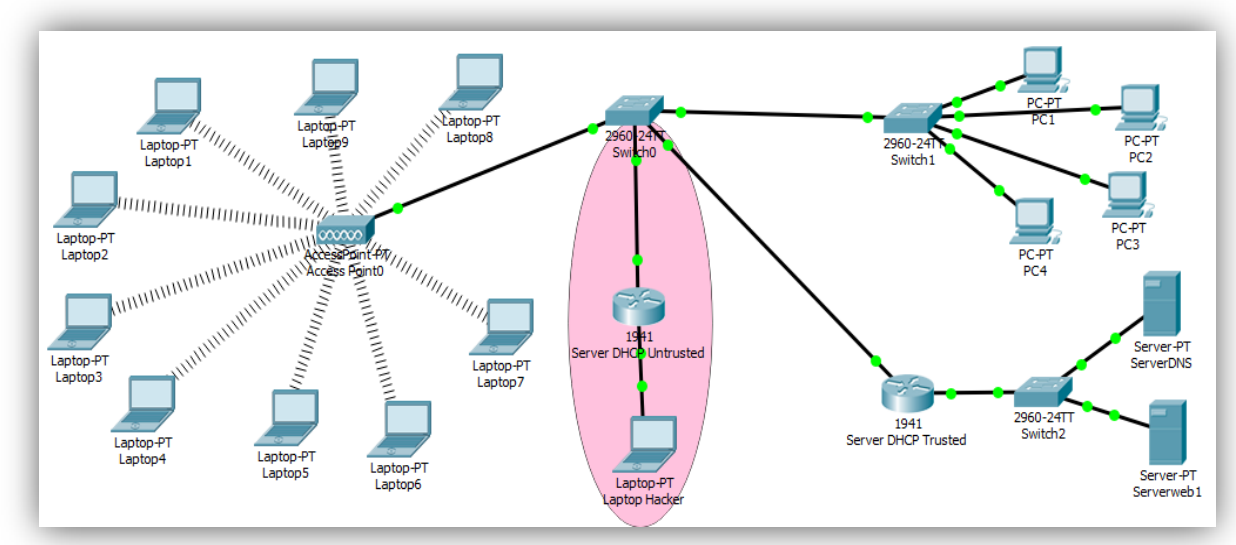

Gambar 5. Topologi Jaringan

Konfigurasi Router sebagai Server DHCP Trusted sebagai berikut:

Router > enable

Router\#configure terminal

Router(config)\#interface g0/0

Router(config-if)\#ip address 192.168.1.1 255.255.255.0

Router(config-if)\#no shutdown

Router(config-if)\#interface g0/1

Router(config-if)\#ip address 8.8.8.1 255.255.255.0

Router(config-if)\#no shutdown

Router(config-if)\#exit

Router(config)\#ip dhcp pool server_trusted

Router(dhcp-config)\#network 192.168.1.0 255.255.255.0

Router(dhcp-config)\#default-router 192.168.1.1

Router(dhcp-config)\#dns-server 8.8.8.8

Router(dhcp-config)\#do wr

Konfigurasi Router sebagai Server DHCP Untrusted sebagai berikut:

Router>enable

Router\#configure terminal

Router(config)\#interface g0/0

Router(config-if)\#ip address 100.10.10.1 255.255.255.0

Router(config-if)\#no shutdown

Router(config-if)\#interface g0/1

Router(config-if)\#ip address 10.10.10.1 255.255.255.0

Router(config-if)\#no shutdown

Router(config-if)\#exit

Router(config)\#ip dhcp pool server_untrusted

Router(dhcp-config)\#network 100.10.10.0 255.255.255.0

Router(dhcp-config)\#default-router 100.10.10.1

Router(dhcp-config)\#dns-server 1.1.1.1

Router(dhcp-config)\#do wr

PC1 sampai dengan PC4 serta laptop1 sampai dengan laptop9 di-setting IP Address menggunakan DHCP. Hasil alamat IP pada masing-masing PC dan Laptop yang terhubung pada jaringan memiliki IP Address yang berbeda, sehingga ada beberapa komputer yang dapat terhubung dengan server dan ada beberapa yang gagal, dikarenakan adanya Server DHCP 
Faktor Exacta 11 (2): 167-178, 2018

p-ISSN: 1979-276X

Untrusted atau tidak dipercaya menyewakan alamat IP pada Komputer yang terhubung pada jaringan.

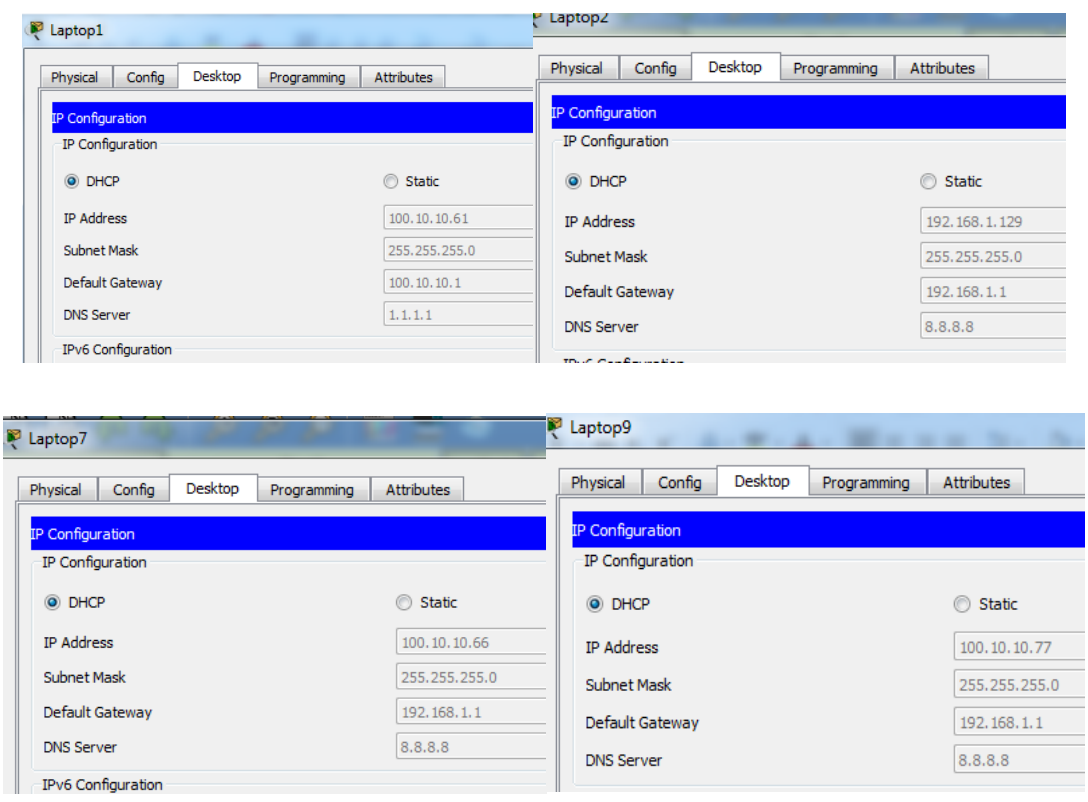

Gambar 6. Pengujian PC dengan DHCP Server Untrusted

Tabel 1. IP Address Tanpa DHCP Snooping

\begin{tabular}{lllllc}
\hline \multicolumn{1}{c}{ Device } & Interface & \multicolumn{1}{c}{$\boldsymbol{I P}$ address } & Subnetmask & Gateway & Dns \\
\hline $\begin{array}{l}\text { Server DHCP } \\
\text { Trusted }\end{array}$ & $\mathrm{Fa} 0 / 0$ & 192.168 .1 .1 & 255.255 .255 .0 & & 8.8 .8 .8 \\
& $\mathrm{Fa} 0 / 1$ & 8.8 .8 .1 & 255.255 .255 .0 & & \\
Server DHCP & $\mathrm{Fa} 0 / 0$ & 100.10 .10 .1 & 255.255 .255 .0 & & 1.1 .1 .1 \\
Untrusted & $\mathrm{Fa} 0 / 1$ & 10.10 .10 .1 & 255.255 .255 .0 & & 1.1 .1 .1 \\
& & & & & \\
PC1 & & 192.168 .1 .110 & 255.255 .255 .0 & 192.168 .1 .1 & 8.8 .8 .8 \\
PC2 & & 100.10 .10 .67 & 255.255 .255 .0 & 100.10 .10 .1 & 1.1 .1 .1 \\
PC3 & & 100.10 .10 .54 & 255.255 .255 .0 & 100.10 .10 .1 & 1.1 .1 .1 \\
PC4 & & 100.10 .10 .52 & 255.255 .255 .0 & 100.10 .10 .1 & 1.1 .1 .1 \\
Laptop1 & & 100.10 .10 .61 & 255.255 .255 .0 & 100.10 .10 .1 & 1.1 .1 .1 \\
Laptop2 & & 192.168 .1 .129 & 255.255 .255 .0 & 192.168 .1 .1 & 8.8 .8 .8 \\
Laptop3 & & 192.168 .1 .116 & 255.255 .255 .0 & 192.168 .1 .1 & 8.8 .8 .8 \\
Laptop4 & & 100.10 .10 .70 & 255.255 .255 .0 & 100.10 .10 .1 & 1.1 .1 .1 \\
Laptop5 & & 100.10 .10 .63 & 255.255 .255 .0 & 100.10 .10 .1 & 1.1 .1 .1 \\
Laptop6 & & 100.10 .10 .71 & 255.255 .255 .0 & 192.168 .1 .1 & 8.8 .8 .8 \\
Laptop7 & & 100.10 .10 .66 & 255.255 .255 .0 & 192.168 .1 .1 & 8.8 .8 .8 \\
Laptop8 & & 100.10 .10 .72 & 255.255 .255 .0 & 100.10 .10 .1 & 1.1 .1 .1 \\
Laptop9 & & 100.10 .10 .77 & 255.255 .255 .0 & 192.168 .1 .1 & 8.8 .8 .8 \\
\hline
\end{tabular}

Pada tabel di atas tampak pada beberapa PC diantaranya PC1, Laptop 2 dan Laptop 3 mendapatkan IP Address, subnetmask dan gateway dari sumber yang terpercaya dan beberapa PC mendapatkan IP Address, subnetmask dan gateway dari sumber yang tidak dipercaya. 
Faktor Exacta 11 (2): 167-178, 2018

p-ISSN: 1979-276X

Pengujian koneksi dilakukan dari PC1 dengan hasil sukses dan PC2 dengan hasil tidak sukses.
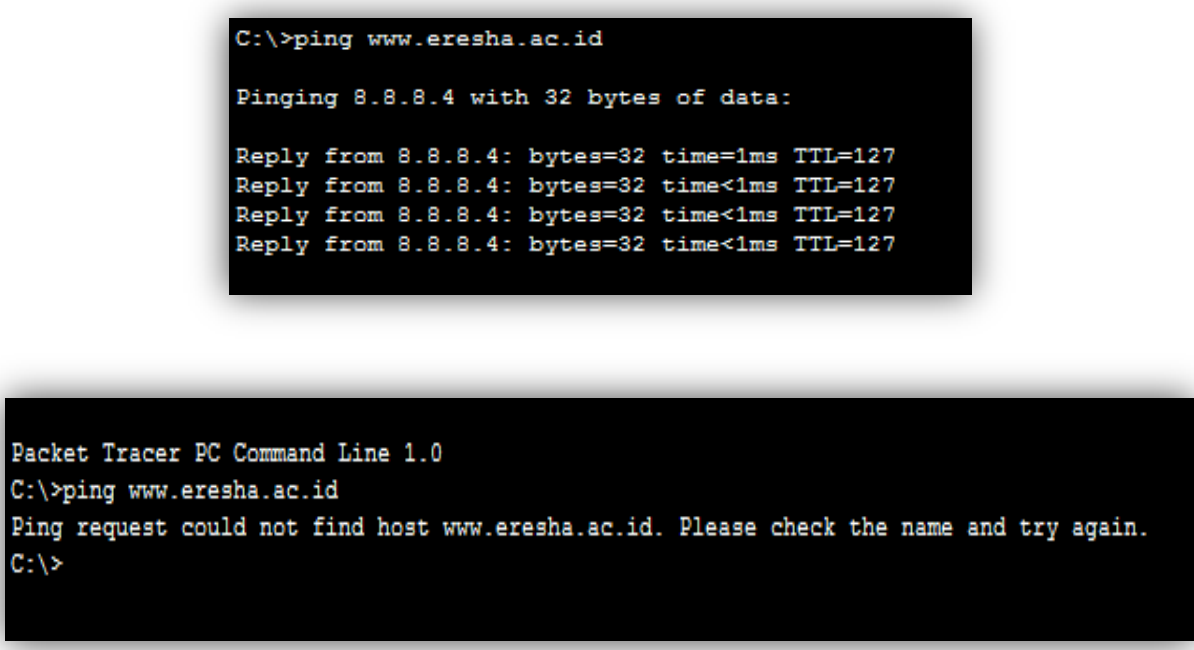

Gambar 7. Pengujian koneksi ke server dengan tanpa DHCP Snooping

Hasil dari perancangan jaringan komputer dimana Switch akan dikonfigurasi menggunakan DHCP Snooping dan VLAN.

Konfigurasi Router sebagai Server DHCP Trusted sebagai berikut:

Router>enable

Router\#configure terminal

Router(config)\#interface g0/0

Router(config-if)\#ip address 192.168.1.1 255.255.255.0

Router(config-if)\#no shutdown

Router(config-if)\#interface g0/1

Router(config-if)\#ip address 8.8.8.1 255.255.255.0

Router(config-if)\#no shutdown

Router(config-if)\#exit

Router(config)\#ip dhcp pool server_trusted

Router(dhcp-config)\#network 192.168.1.0 255.255.255.0

Router(dhcp-config)\#default-router 192.168.1.1

Router(dhcp-config)\#dns-server 8.8.8.8

Router(dhcp-config)\#exit

Router(config)\#ip dhcp relay information trust-all

Router(config)\#do write

Konfigurasi Router sebagai Server DHCP Untrusted sebagai berikut:

Router > enable

Router\#configure terminal

Router(config)\#interface g0/0

Router(config-if)\#ip address 100.10.10.1 255.255.255.0

Router(config-if)\#no shutdown

Router(config-if)\#interface g0/1

Router(config-if)\#ip address 10.10.10.1 255.255.255.0

Router(config-if)\#no shutdown

Router(config-if)\#exit 
Router(config)\#ip dhcp pool server_untrusted

Router(dhcp-config)\#network 100.10.10.0 255.255.255.0

Router(dhcp-config)\#default-router 100.10.10.1

Rou (deriramdani, 2014)ter(dhcp-config)\#dns-server 1.1.1.1

Router(dhcp-config)\#do write

\section{Konfigurasi pada Switch}

Konfigurasi pada Switch0 dan Switch1 yaitu untuk melakukan filter terhadap port pada switch yang digunakan untuk membatasi penggunaan server $D H C P$ yaitu menggunakan metode DHCP Snooping.

Langkah Membuat Vlan dengan id 10 dan nama dhcp_snooping pada Switch0 :

Switch >nable

Switch\#configure terminal

Switch(config)\#vlan 10

Switch(config-vlan)\#name dhcp_snooping

Switch(config)\#int range fa0/1-24

Switch(config-if-range)\#switchport mode access

Switch(config-if-range)\#switchport access vlan 10

Switch > enable

Switch\#configure terminal

Switch(config)\#ip dhcp snooping

Switch(config)\#ip dhcp snooping vlan 10

Switch(config)\#interface fa0/1

Switch(config-if)\#ip dhcp snooping trust

Switch(config)\#int fa0/20

Switch(config-if)\#ip dhcp snooping trust

Perintah di atas membuat VLAN id 10 dengan nama dhcp_snooping sedangkan interface mulai FastEthernet0/1-24 mode acces diubah menjadi VLAN 10.

Perintah IP dhcp snooping mengaktifkan switch dhcp snooping dan interface FastEthernet0/1 dan FastEthernet0/20 menjadi port yang dipercaya sebagai DHCP_SERVER.

Membuat Vlan dengan id 10 dan nama dhcp_snooping pada Switch1:

Switch>enable

Switch\#configure terminal

Switch(config)\#vlan 10

Switch(config-vlan)\#name dhcp_snooping

Switch(config)\#int range fa0/1-24

Switch(config-if-range)\#switchport mode access

Switch(config-if-range)\#switchport access vlan 10

Switch>enable

Switch\#configure terminal

Switch(config)\#ip dhcp snooping

Switch(config)\#ip dhcp snooping vlan 1

Switch(config)\#int faO/l

Switch(config-if)\#ip dhcp snooping trust

Perintah di atas membuat VLAN id 10 dengan nama dhcp_snooping sedangkan interface FastEthernet0/1-24 yaitu port yang tersedia pada switch mulai dari port 1 sampai dengan port 24 dirubah mode acces dari VLAN 1 dengan nama default menjadi VLAN 10 dengan nama dhcp snooping.

Perintah IP dhcp snooping trust pada interface FastEthernet0/1 adalah perintah untuk mengaktifkan switch dhcp snooping pada port atau interface FastEthernet $0 / 1$ menjadi port yang dipercaya sebagai DHCP_SERVER, sedangkan port selainnya tidak dapat digunakan untuk Server DHCP. 

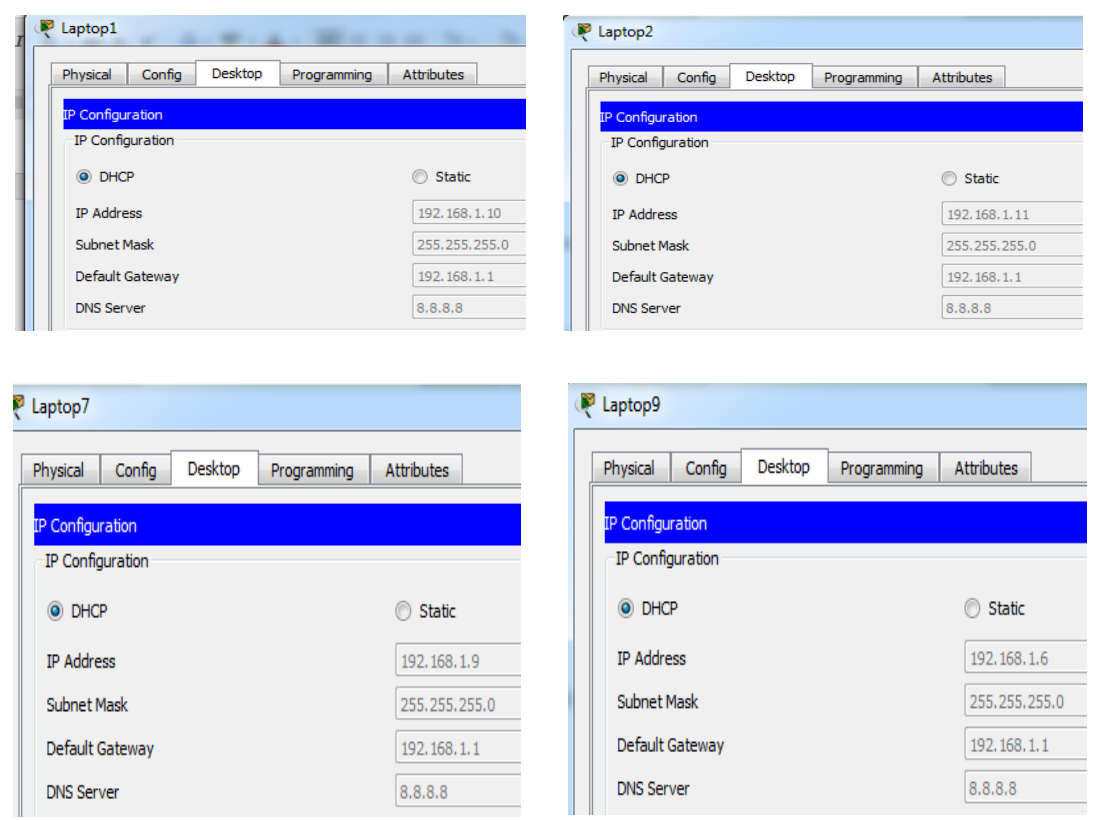

Gambar 8. Pengujian PC dengan DHCP Server Trusted

Tabel 2. IP Address Menggunakan DHCP Snooping

\begin{tabular}{lllllc}
\hline \multicolumn{1}{c}{ Device } & Interface & \multicolumn{1}{c}{ IP address } & Subnetmask & Gateway & Dns \\
\hline Server & Fa0/0 & 192.168 .1 .1 & 255.255 .255 .0 & & 8.8 .8 .8 \\
DHCP & Fa0/1 & 8.8 .8 .1 & 255.255 .255 .0 & & \\
Trusted & & & & & \\
Server & Fa0/0 & 100.10 .10 .1 & 255.255 .255 .0 & & 1.1 .1 .1 \\
DHCP & Fa0/1 & 10.10 .10 .1 & 255.255 .255 .0 & & 1.1 .1 .1 \\
Untrusted & & & & & \\
& & & & & \\
PC1 & & 192.168 .1 .2 & 255.255 .255 .0 & 192.168 .1 .1 & 8.8 .8 .8 \\
PC2 & & 192.168 .1 .5 & 255.255 .255 .0 & 192.168 .1 .1 & 8.8 .8 .8 \\
PC3 & & 192.168 .1 .3 & 255.255 .255 .0 & 192.168 .1 .1 & 8.8 .8 .8 \\
PC4 & & 192.168 .1 .4 & 255.255 .255 .0 & 192.168 .1 .1 & 8.8 .8 .8 \\
Laptop1 & & 192.168 .1 .10 & 255.255 .255 .0 & 192.168 .1 .1 & 8.8 .8 .8 \\
Laptop2 & & 192.168 .1 .11 & 255.255 .255 .0 & 192.168 .1 .1 & 8.8 .8 .8 \\
Laptop3 & & 192.168 .1 .7 & 255.255 .255 .0 & 192.168 .1 .1 & 8.8 .8 .8 \\
Laptop4 & & 192.168 .1 .14 & 255.255 .255 .0 & 192.168 .1 .1 & 8.8 .8 .8 \\
Laptop5 & & 192.168 .1 .12 & 255.255 .255 .0 & 192.168 .1 .1 & 8.8 .8 .8 \\
Laptop6 & & 192.168 .1 .15 & 255.255 .255 .0 & 192.168 .1 .1 & 8.8 .8 .8 \\
Laptop7 & & 192.168 .1 .9 & 255.255 .255 .0 & 192.168 .1 .1 & 8.8 .8 .8 \\
Laptop8 & & 192.168 .1 .8 & 255.255 .255 .0 & 192.168 .1 .1 & 8.8 .8 .8 \\
Laptop9 & & 192.168 .1 .6 & 255.255 .255 .0 & 192.168 .1 .1 & 8.8 .8 .8 \\
\hline
\end{tabular}

Pada tabel di atas tampak pada seluruh PC dan Laptop mendapatkan IP Address, subnetmask dan gateway dari sumber yang terpercaya sedangkan Server DHCP Untrusted tidak dapat memberikan IP Address dan Gateway pada komputer client yang terhubung pada jaringan. 
Tabel 3. Perbandingan IP Address Menggunakan DHCP Snooping dan Tanpa DHCP Snooping

\begin{tabular}{lllllll}
\hline Device & \multicolumn{3}{c}{ Hasil DHCP Snooping } & \multicolumn{3}{c}{ Hasil Tanpa DHCP Snooping } \\
& & & & & & \\
& IP address & Gateway & DNS & IP address & Gateway & DNS \\
\hline & & & & & & \\
PC1 & 192.168 .1 .2 & 192.168 .1 .1 & 8.8 .8 .8 & 192.168 .1 .110 & 192.168 .1 .1 & 8.8 .8 .8 \\
PC2 & 192.168 .1 .5 & 192.168 .1 .1 & 8.8 .8 .8 & 100.10 .10 .67 & 100.10 .10 .1 & 1.1 .1 .1 \\
PC3 & 192.168 .1 .3 & 192.168 .1 .1 & 8.8 .8 .8 & 100.10 .10 .54 & 100.10 .10 .1 & 1.1 .1 .1 \\
PC4 & 192.168 .1 .4 & 192.168 .1 .1 & 8.8 .8 .8 & 100.10 .10 .52 & 100.10 .10 .1 & 1.1 .1 .1 \\
Laptop1 & 192.168 .1 .10 & 192.168 .1 .1 & 8.8 .8 .8 & 100.10 .10 .61 & 100.10 .10 .1 & 1.1 .1 .1 \\
Laptop2 & 192.168 .1 .11 & 192.168 .1 .1 & 8.8 .8 .8 & 192.168 .1 .129 & 192.168 .1 .1 & 8.8 .8 .8 \\
Laptop3 & 192.168 .1 .7 & 192.168 .1 .1 & 8.8 .8 .8 & 192.168 .1 .116 & 192.168 .1 .1 & 8.8 .8 .8 \\
Laptop4 & 192.168 .1 .14 & 192.168 .1 .1 & 8.8 .8 .8 & 100.10 .10 .70 & 100.10 .10 .1 & 1.1 .1 .1 \\
Laptop5 & 192.168 .1 .12 & 192.168 .1 .1 & 8.8 .8 .8 & 100.10 .10 .63 & 100.10 .10 .1 & 1.1 .1 .1 \\
Laptop6 & 192.168 .1 .15 & 192.168 .1 .1 & 8.8 .8 .8 & 100.10 .10 .71 & 192.168 .1 .1 & 8.8 .8 .8 \\
Laptop7 & 192.168 .1 .9 & 192.168 .1 .1 & 8.8 .8 .8 & 100.10 .10 .66 & 192.168 .1 .1 & 8.8 .8 .8 \\
Laptop8 & 192.168 .1 .8 & 192.168 .1 .1 & 8.8 .8 .8 & 100.10 .10 .72 & 100.10 .10 .1 & 1.1 .1 .1 \\
Laptop9 & 192.168 .1 .6 & 192.168 .1 .1 & 8.8 .8 .8 & 100.10 .10 .77 & 192.168 .1 .1 & 8.8 .8 .8 \\
\hline
\end{tabular}

Pengujian dilakukan dari PC1 dan PC2 menggunakan DHCP Snooping dengan hasil Sukses.
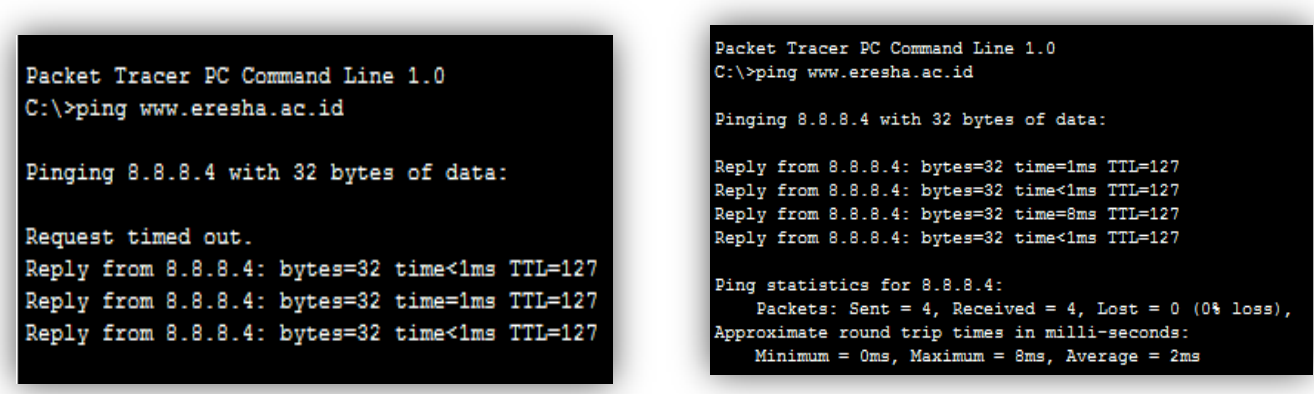

Gambar 9. Pengujian koneksi ke server dengan DHCP Snooping

\section{PENUTUP}

\section{Simpulan}

Berdasarkan uji coba implementasi secara simulasi dengan menggunakan software cisco packet tracer 7.1 maka dapat disimpulkan:

1. DHCP Snooping dapat memfilter dan memvalidasi terhadap port yang terpercaya dan yang tidak dipercaya.

2. Dengan menggunakan DHCP Snooping jaringan komputer akan lebih aman tidak terganggu dengan adanya server DHCP yang lain atau palsu.

3. VLAN dapat menghubungkan jaringan berdasarkan VLAN ID atau Group sehingga Komputer yang bukan Group tidak dapat terhubung dalam sebuah jaringan.

\section{Saran}

DHCP Snooping merupakan teknik dasar dalam keamanan pada jaringan komputer dan internet, untuk pengembangan lebih lanjut dapat di analisis tentang keamanan yang lebih besar 
seperti kombinasi DHCP Snooping, VLAN, ACL dan DHCP starvation agar lebih memperkuat keamanan jaringan.

\section{DAFTAR PUSTAKA}

Ariyadi, T. (2017). Desain Keamanan DHCP Snooping untuk Mengurangi Serangan. JUSIKOM, Vol 2, No. 1, Juni, 28-36.

BPPT, C. . (2014). Panduan Penanganan Insiden Keamanan Jaringan. Indonesia: CSIRT Badan Pengkajian dan Penerapan Teknologi.

Deriramdani. (2014, november 22). http://blog.umy.ac.id. Retrieved from http://blog.umy.ac.id.

Mufadhol. (2012). Simulasi Jaringan Komputer Menggunakan Cisco Packet Tracer. JURNAL TRANSFORMATIKA, Volume, No. 2, Januari, 64-71.

Prasetiono, S. J. (2010). Teknik Keamanan Access Point pada Jaringan Nirkabel . Majalah Ilmiah IC Tech Vol 5 No 1Januari, 17-22.

Sofana, I. (2009). CISCO CCNA dan Jaringan Komputer. Bandung: Informatika.

Sulaiman, O. K. (2016). Analisis Sistem Keamanan Jaringan dengan Menggunakan Switch Port Security. CESS (Journal Of Computer Engineering, System And Science) Vol 1, No 1, Januari , 9-14.

Tarkaa, N. S., Iannah, P. I., \& Iber, I. T. (2017). Design and Simulation of Local Area Network Using Cisco Packet Tracer. The International Journal of Engineering and Science (IJES) Volume 6 Issue 10 , 63- 77. 